\title{
Inducible Production of Nitric Oxide in Osteoblast-like Cells and in Fetal Mouse Bone Explants Is Associated with Suppression of Osteoclastic Bone Resorption
}

Clemens W. G. M. Löwik, Peter H. Nibbering, “ Marjan van de Ruit, and Socrates E. Papapoulos

Departments of Endocrinology and *Infectious Diseases, University Hospital Leiden,

Rijnsburgerweg 10, 2333 AA Leiden, The Netherlands

\begin{abstract}
Nitric oxide (NO) has been suggested to be involved in the regulation of osteoclast activity. Since osteoblasts, through the release of various factors, are the main regulators of osteoclastic resorption, first we have investigated whether osteoblastlike cells and fetal mouse long bone explants are able to produce NO. Second, we have assessed the effect of NO on osteoclastic resorption in whole bone cultures. In this study we show that primary rat osteoblast-like cells as well as the clonal rat osteoblast-like cell line UMR-106, stimulated with IFN- $\gamma$ together with TNF- $\alpha$ and LPS, produce NO, measured as nitrite production. IL-1 $\alpha$ enhanced while TGF- $\beta 2$ inhibited TNF- $\alpha$ + IFN- $\gamma$ + LPS-stimulated NO production in UMR-106 cells dose dependently. Both the cytokines, however, had no effect when given alone. The competitive inhibitor of $\mathrm{NO}$ production, $N^{G}$-monomethyl-arginine (L-NMMA), and cycloheximide abolished the increase in nitrite production induced by TNF- $\alpha$ + IFN- $\gamma+$ LPS, while hydrocortisone had no effect, as previously reported for chondrocytes. Calciotropic hormones had either no effect $\left[1,25(\mathrm{OH})_{2} \mathrm{D}_{3}\right]$ or had a small inhibitory effect (parathyroid hormone) on stimulated NO production. Furthermore, we found that in cultured fetal mouse long bone explants the combination of TNF- $\alpha+$ IFN- $\gamma+$ LPS as well as the NO donor sodium nitroprusside could inhibit osteoclastic resorption, measured as ${ }^{45} \mathrm{Ca}$ release. The inhibition of resorption was prevented by concurrent administration of L-NMMA. Histological evaluation revealed that the TNF- $\alpha+$ IFN- $\boldsymbol{\gamma}+$ LPS-induced inhibition of ${ }^{45} \mathrm{Ca}$ release was associated with a decrease in the number of tartrate-resistant acid phosphatase-positive osteoclasts. We propose that the NO production by osteogenic cells (osteoblasts and chondrocytes) may represent an important regulatory mechanism of osteoclastic activity especially under pathological conditions characterized by release of boneresorbing inflammatory cytokines. (J. Clin. Invest. 1994. 93:1465-1472.) Key words: nitric oxide • osteoblasts • bone • osteoclasts • resorption
\end{abstract}

Parts of the findings described in this paper have been published in abstract form (1993. Calcif. Tissue Int. 52 [Suppl. 1]:S13. [Abstr. 49]). Address correspondence to Dr. C. W. G. M. Löwik, Department of Endocrinology, University Hospital, Bldg. 1, C4-R89, Rijnsburgerweg 10, 2333 AA Leiden, The Netherlands.

Received for publication 20 August 1993 and in revised form 1 November 1993.

J. Clin. Invest.

(C) The American Society for Clinical Investigation, Inc. $0021-9738 / 94 / 04 / 1465 / 08 \$ 2.00$

Volume 93, April 1994, 1465-1472

\section{Introduction}

Nitric oxide (NO) ${ }^{1}$ is a recently identified messenger molecule regulating a wide range of functions throughout the body (for review see references $1-3$ ). NO is synthesized from L-arginine by NO-synthase (NOS), and can act as a neurotransmitter in the brain and peripheral nervous system; it has been identified as the endothelial-derived relaxation factor, which binds to guanylate cyclase leading to cGMP formation and subsequent smooth muscle relaxation. NO can also contribute to immune function since NO produced by macrophages is involved in their tumoricidal and bactericidal actions (4-6).

At present three distinct forms of NOS have been identified and cloned (7-9). In neurons and brain (cerebellar type) and blood vessels (endothelial type), NOS is constitutive and $\mathrm{Ca}^{2+}$ dependent $(7,8)$, whereas in macrophages $(9)$, hepatocytes (10), fibroblasts (11), and chrondrocytes (12-14) (macrophage type), the enzyme activity is induced by cytokines and endotoxins.

Using isolated osteoclasts, it has recently been shown that NO acts directly on the osteoclast to produce a major shape change. These shape changes were associated with a reduction of bone resorption after a 24-h incubation of isolated osteoclasts on devitalized bone slices. These effects of NO were not mediated by cGMP or changes in intracellular calcium (15). These authors suggested that NO-producing endothelial cells in bone marrow in the proximity of osteoclasts could regulate osteoclast activity. However, it is well established that the osteogenic cells (osteoblasts and chondrocytes) are the main regulators of osteoclastic resorption, through the release of proteases, cytokines, and other factors $(16,17)$. The aim of this study was to investigate first whether osteoblast-like cells and fetal mouse long bones are able to produce NO, and second, to assess the effect of NO on osteoclastic resorption in fetal mouse long bone cultures.

\section{Methods}

Materials. $\alpha$ MEM and RPMI were purchased from Gibco Laboratories (Grand Island, NY), and penicillin, streptomycin, and FCS were from Flow Laboratories (Amstelstad, Zwanenburg, The Netherlands). Recombinant human TNF- $\alpha$ was from Boehringer Ingelheim (Ingelheim, Germany). Recombinant human IL-1 $\alpha$ was a gift from Dr. P. Lomedico (Hoffman-La Roche Inc., Nutley, NJ), recombinant rat IFN- $\gamma$ from Dr. P. H. van der Meide (Institute of Applied Radiobiology and Immunology, Rijswijk, The Netherlands), and recombinant TGF- $\beta 2$ from Dr. J. H. M. Feijen (Sandoz, Basel, Switzerland). LPS from Escherichia coli was obtained from Difco Laboratories Inc. (Detroit, MI), and $N^{\mathrm{G}}$-monomethyl-L-arginine (L-NMMA) and sodium

1. Abbreviations used in this paper: L-NMMA, $N^{\mathrm{G}}$-monomethyl-L-arginine; NO, nitric oxide; NOS, nitric oxide synthase; $\mathrm{NO}_{2}{ }^{-}$, nitrite; PTH, parathyroid hormone. 
nitroprusside (SNP) from Calbiochem-Behring Corp. (San Diego, CA ). All other chemicals used were of highest quality available.

Cell cultures. Primary cultures of rat osteoblast-like cells were prepared from 20-d-old fetal rat calvaria by the sequential collagenase method (18). ROB were cultured in a 24-well culture cluster (Greiner Labortechnik, Frickenhausen, Germany) in $\alpha$ MEM supplemented with $10 \%$ FCS, gentamycin $(9 \mathrm{mg} / 100 \mathrm{ml})$, and glucose $(100 \mathrm{mg} / 100$ $\mathrm{ml}$ ). UMR-106, a clonal rat osteogenic sarcoma cell line with a characterized osteoblast phenotype (19), was a gift of Dr. T. J. Martin (St. Vincent's Institute for Medical Research, Melbourne, Australia). UMR-106 cells were cultured in $\alpha$ MEM supplemented with 5\% FCS and antibiotics.

Bone resorption assay. Pregnant Swiss albino mice were injected intraperitoneally with $30 \mu \mathrm{Ci}{ }^{45} \mathrm{Ca}$ (sp act, $1 \mathrm{Ci} / \mathrm{mmol}$; Amersham International, Amersham, UK) on day 16 of gestation, whereby vaginal plug discovery was defined as day 0 of gestation. $1 \mathrm{~d}$ later the animals were killed by servical dislocation. The ${ }^{45} \mathrm{Ca}$-prelabeled bone shafts of radii were disected out in Hepes-buffered Hank's solution ( $\mathrm{pH}$ 7.4 ) as described (20). Shafts of radii were cultured in a 24-well plates in $\alpha \mathrm{MEM}+10 \%$ heat-inactivated FCS and antibiotics in a final volume of $500 \mu \mathrm{l}$. Explants were precultured for $24 \mathrm{~h}$ to allow the calcium exchange with the medium to reach a steady state and then cultured for $4 \mathrm{~d}$ in similar medium with or without the agents to be tested. Cultures were performed at $37^{\circ} \mathrm{C}$ in a humidified atmosphere of $5 \% \mathrm{CO}_{2}$. At the end of the culture period, $250 \mu \mathrm{l}$ of the medium was used for determination of the amount of ${ }^{45} \mathrm{Ca}$ released from the bone explants, whereas the other $250 \mu \mathrm{l}$ was used for determination of the nitrite content. Residual calcium was extracted from the bones in $0.5 \mathrm{ml} 5 \%$ TCA for $24 \mathrm{~h}$. In some experiments bones were fixed and processed for histology. The amounts of ${ }^{45} \mathrm{Ca}$ in the culture media and in the decalcification fluids were determined in a liquid scintillation counter.

Calculation of osteoclastic resorption. Resorption was expressed as the percentage ${ }^{45} \mathrm{Ca}$ in the prelabeled explant that is released during incubation ( $\%{ }^{45} \mathrm{Ca}$ release). The values were corrected for physicochemical calcium exchange by substraction of the percentage ${ }^{45} \mathrm{Ca}$ release from a dead bone (percentage killed control [\% KCo]). Bones were killed by three cycles of freeze-thawing. Osteoclastic resorption is thus calculated as:

$\%$ net ${ }^{45} \mathrm{Ca}$ release $=\frac{{ }^{45} \mathrm{Ca} \text { release into medium }(\mathrm{cpm})}{\text { total }^{45} \mathrm{Ca} \text { incorporated in bone }(\mathrm{cpm})}$

$\times 100 \%-\%$ KCo release.

Histology. At the end of the culture period, the bone explants were fixed in $10 \%$ neutral-buffered formalin for $24 \mathrm{~h}$ at $4^{\circ} \mathrm{C}$ and subsequently decalcified in $5 \%$ formic acid and $5 \%$ formalin for $3 \mathrm{~h}$ at $4^{\circ} \mathrm{C}$. The explants were then processed for demonstration of tartrate-resistant acid phosphatase activity according to the en bloc staining method of Scheven et al. (21), using naphtol AS-BI phosphate as substrate, pararosalin as coupler, and $10 \mathrm{mM}$ L-tartrate as inhibitor. Paraffin sections $5 \mu \mathrm{m}$ thick were counterstained with hematoxylin.

Nitrite production. NO was measured as nitrite production in culture medium of confluent cultures after $24 \mathrm{~h}$ of incubation. Nitrite is the stable end product of $\mathrm{NO}$ and has been shown to be a good reflection of NO production. The amount of nitrite $\left(\mathrm{NO}_{2}^{-}\right)$released by cells or bone explants was determined using the Griess reagent consisting of $1 \%$ sulfanylamide, $0.1 \%$ naphtylethelene-diamine-dihydrochloride, and $2.5 \% \mathrm{H}_{3} \mathrm{PO}_{4}$. Briefly, $75 \mu$ l culture supernatant was mixed with 75 $\mu \mathrm{l}$ Griess reagent and incubated in a 96-well plate for $15 \mathrm{~min}$ at room temperature under continuous shaking. $\mathrm{NO}_{2}^{-}$concentration, proportional to $\mathrm{OD}_{550}$, was determined using a microtiterplate reader (Ther$\operatorname{momax}^{\mathrm{TM}}$, Molecular Devices, Menlo Park, CA) with reference to a standard curve of serial dilutions of $\mathrm{NaNO}_{2}$. Total cellular protein content was measured with the BCA protein assay (Pierce Chemical Co., Rockford, IL). The results are expressed as nanomoles $\mathrm{NO}_{2}^{-}$per miligram cellular protein.

Statistics. Values are expressed as means \pm SEM. Statistical differences between the values were examined by one-way ANOVA for multiple comparisons followed by Fisher's test.

\section{Results}

NO production by rat osteoblast-like cells. In unstimulated confluent cultures of primary fetal rat osteoblast-like cells a spontaneous production of $\mathrm{NO}_{2}^{-}$was found that was stimulated significantly after a $24-\mathrm{h}$ incubation with IFN- $\gamma(100 \mathrm{U} /$ $\mathrm{ml})$ and LPS ( $10 \mathrm{ng} / \mathrm{ml})$ or a combination of the two. TNF- $\alpha$ $(100 \mathrm{ng} / \mathrm{ml})$ alone did not stimulate $\mathrm{NO}_{2}{ }^{-}$production, but in combination with IFN- $\gamma$ or LPS enhanced $\mathrm{NO}_{2}^{-}$production significantly compared with the single stimuli. The most potent stimulus of $\mathrm{NO}_{2}^{-}$production was the combination of TNF- $\alpha$ + IFN- $\gamma+$ LPS (Fig. $1 A$ ). Similar results were found when primary mouse osteoblasts were used (results not shown). We also performed the same experiments with the clonal rat osteogenic sarcoma cell line UMR-106, which has a well-characterized osteoblast-like phenotype (19). UMR-106 cells did not produce $\mathrm{NO}_{2}^{-}$spontaneously, but when the cells were stimulated by TNF- $\alpha$ together with LPS or IFN- $\gamma$, or the combination of the three, a significant increase in $\mathrm{NO}_{2}^{-}$production was measured (Fig. $1 B$ ). Since the UMR-106 cells are osteoblastlike cells of clonal origin and can be stimulated to produce $\mathrm{NO}_{2}^{-}$similar to $\mathrm{ROB}$, they were used in all further studies unless otherwise indicated.
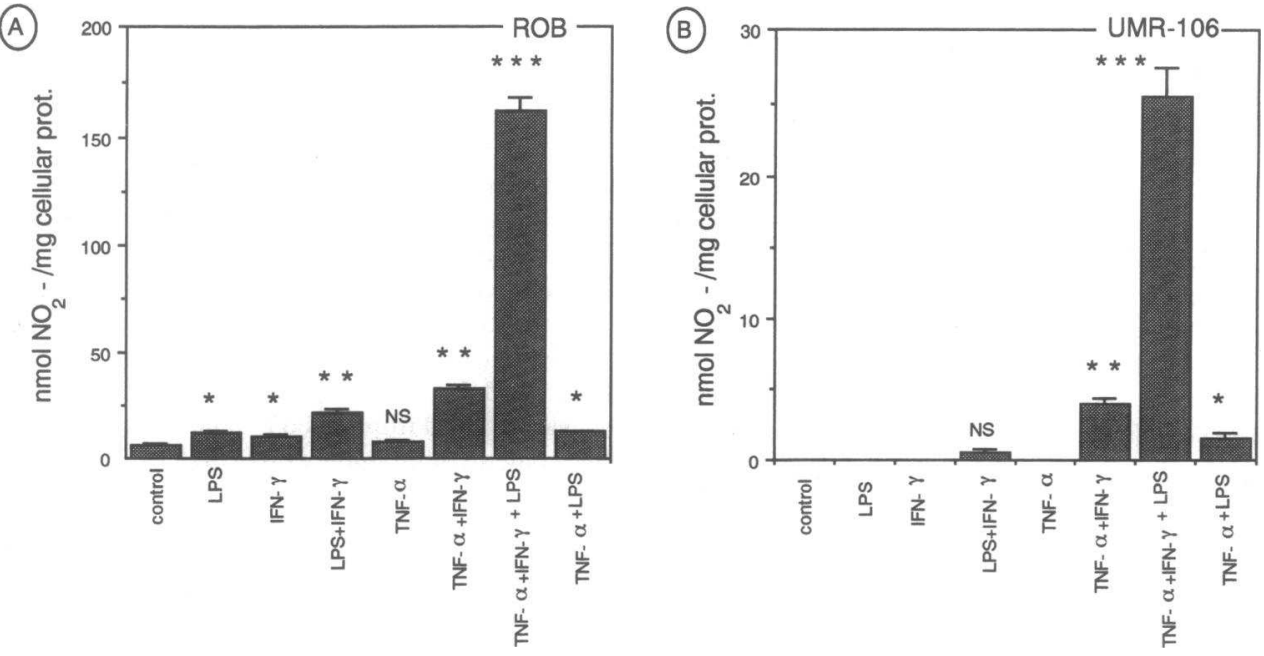

Figure 1. Effect of LPS (10 ng/ $\mathrm{ml})$, IFN- $\gamma(100 \mathrm{U} / \mathrm{ml})$, TNF- $\alpha$ $(100 \mathrm{ng} / \mathrm{ml})$, or combination of these on $\mathrm{NO}_{2}^{-}$production by $(A)$ primary rat osteoblast-like cells $(\mathrm{ROB})$, and $(B)$ the clonal rat osteoblast-like cell line UMR-106. Confluent cultures were incubated with the additives for $24 \mathrm{~h}$. Data ( $\mathrm{nmol}$ $\mathrm{NO}_{2}{ }^{-} / \mathrm{mg}$ cellular protein) are means \pm SEM of three experiments, each performed in triplicate. ${ }^{*} P<0.05,{ }^{* *} P<0.01$, $* * * P<0.001 . N S$, not significant. 
Time course of NO production. To determine the time course of the response, UMR-106 cells were cultured to confluence and stimulated with TNF- $\alpha+$ IFN- $\gamma+$ LPS. Significant amounts of $\mathrm{NO}_{2}^{-}$were measured after a lag period of $6 \mathrm{~h}$, and increased further during the next $18 \mathrm{~h}$ followed by a much slower secondary increase up to $72 \mathrm{~h}$ (Fig. 2). In all further experiments $\mathrm{NO}_{2}^{-}$production by cells was determined in the culture medium after $24 \mathrm{~h}$ of incubation with or without stimuli.

Dose-response studies with a combination of $T N F-\alpha+L P S$ $+I F N-\gamma$. Three dose-response experiments with a combination of TNF- $\alpha+$ LPS + IFN- $\gamma$ were performed. In these the concentration of one of the stimuli varied while the concentrations of the other two were kept constant. All stimuli increased NO production dose dependently (Fig. 3 ).

Partial characterization of NO induction. The increase in the amount of $\mathrm{NO}_{2}^{-}$induced by TNF- $\alpha+$ LPS + IFN- $\gamma$ could be inhibited by simultaneous addition of $1 \mathrm{mM}$ of the competitive inhibitor of NOS, L-NMMA, or by $10^{-6} \mathrm{M}$ cycloheximide (Table I). Hydrocortisone, at concentrations of $10^{-8}$ and $10^{-7}$ M, had no significant effect on the TNF- $\alpha+$ LPS + IFN- $\gamma-$ stimulated $\mathrm{NO}_{2}^{-}$production.

Effects of IL-1 $\alpha$ parathyroid hormone (PTH), and dibutyryl-cAMP on stimulated NO production. IL-1 $\alpha$ synergistically stimulated TNF- $\alpha+$ IFN- $\gamma$ or TNF- $\alpha+$ INF- $\gamma$ + LPS-induced $\mathrm{NO}_{2}^{-}$production, but was ineffective on its own (Fig. 4). $4 \cdot 10^{-8} \mathrm{M}$ PTH( (1-34) alone or in combination with TNF- $\alpha$ + IFN- $\gamma$ did not affect $\mathrm{NO}_{2}^{-}$production in UMR-106 cells. However, in the presence of the combination of TNF- $\alpha+$ IFN$\gamma+$ LPS, PTH significantly inhibited $\mathrm{NO}_{2}^{-}$production. The inhibitory effect of PTH could be mimicked by 0.1 and $1.0 \mathrm{mM}$ dBcAMP (Fig. 4).

Dose-response of $I L-1 \alpha$ and TGF- $\beta 2$ on stimulated NO production. Fig. 5 shows the effect of various doses of IL- $1 \alpha$ and TGF- $\beta 2$ on TNF- $\alpha+$ IFN- $\gamma+$ LPS-stimulated NO production. IL-1 further increased stimulated NO production dose dependently. In contrast, TGF- $\beta 2$ dose-dependently inhibited TNF- $\alpha+$ IFN- $\gamma+$ LPS-induced NO production. TGF- $\beta 2$ also inhibited TNF- $\alpha+$ IFN- $\gamma$-stimulated NO production but was ineffective on its own (results not shown).

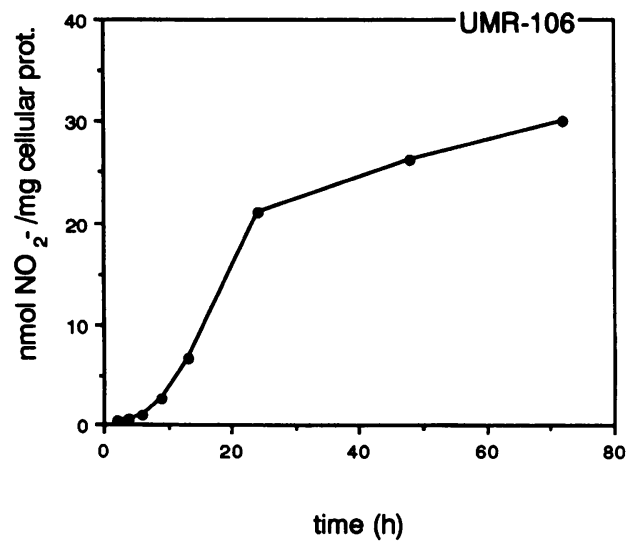

Figure 2. Time course of $\mathrm{NO}_{2}^{-}$production by confluent cultures of UMR-106 cells stimulated with a combination of TNF- $\alpha(100 \mathrm{ng} / \mathrm{ml})$ + IFN- $\gamma(100 \mathrm{U} / \mathrm{ml})+\mathrm{LPS}(10 \mathrm{ng} / \mathrm{ml})$. Data $\left(\mathrm{nmol} \mathrm{NO}{ }_{2}^{-} / \mathrm{mg}\right.$ cellular protein) are the means of two experiments, each performed in quadruplicate. Variation in the mean values are never $>5 \%$.
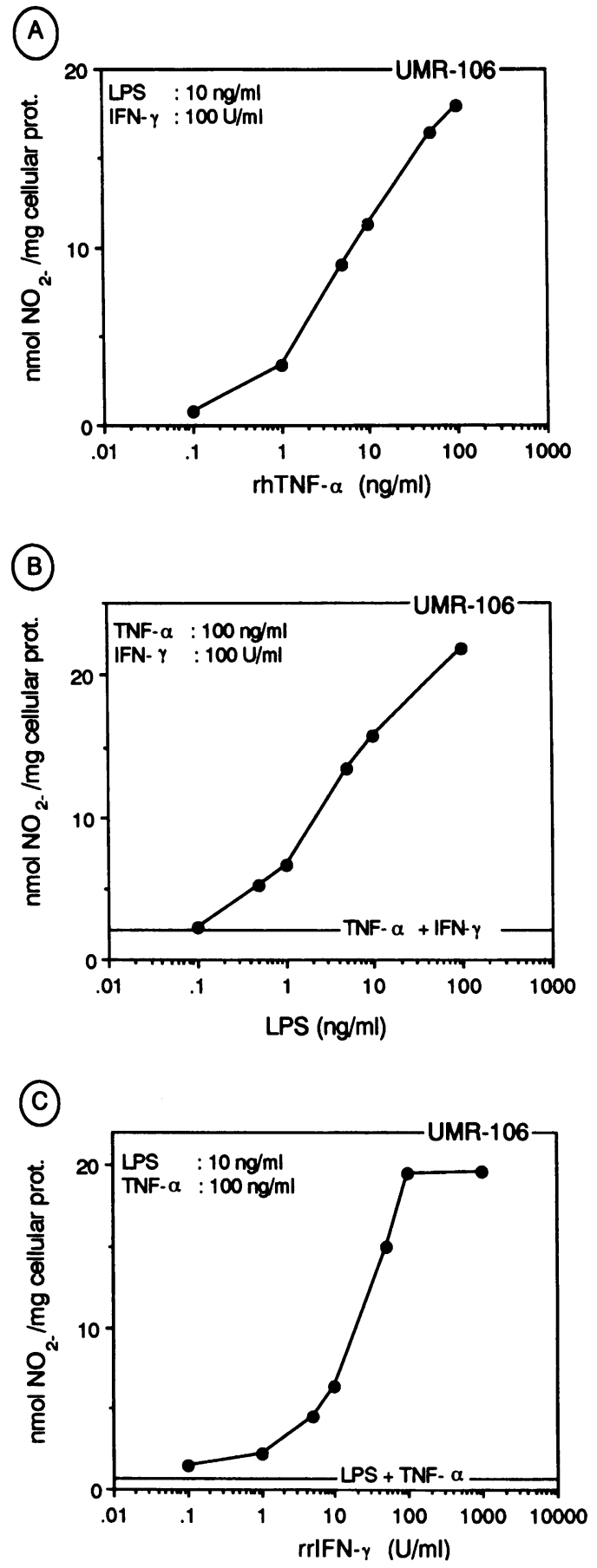

Figure 3. Dose-response curves of the effects of combinations of TNF- $\alpha+$ LPS + IFN- $\gamma$ on $\mathrm{NO}_{2}{ }^{-}$production by UMR-106 cells after $24 \mathrm{~h}$ of incubation. In these experiments the concentrations of two of the stimuli were kept constant whereas the concentration of one of the stimuli varied. $(A)$ Dose-response of recombinant human TNF- $\alpha$ in the presence of $10 \mathrm{ng} / \mathrm{ml} \mathrm{LPS} \mathrm{and} 100 \mathrm{U} / \mathrm{ml} \mathrm{IFN-} \gamma .(B)$ Dose-response of LPS in the presence of $100 \mathrm{ng} / \mathrm{ml} \mathrm{TNF-} \alpha$ and $100 \mathrm{U} / \mathrm{ml}$ IFN- $\gamma .(C)$ Dose-response of recombinant rat IFN- $\gamma$ in the presence of $10 \mathrm{ng} / \mathrm{ml} \mathrm{LPS}$ and $100 \mathrm{ng} / \mathrm{ml} \mathrm{TNF}-\alpha$. Data $\left(\mathrm{nmol} \mathrm{NO}{ }_{2}{ }^{-} / \mathrm{mg}\right.$ cellular protein) are the means of two experiments, each performed in quadruplicate. Variation in the mean values are never $>5 \%$.

Relation between NO production and osteoclastic resorption in cultured fetal mouse long bones. We next investigated whether NO production could be induced in fetal mouse long bone explants and whether this is related to changes in osteo- 
Table I. Effects of Various Compounds on $\mathrm{NO}_{2}^{-}$Production by the Osteoblast-like Cell Line UMR-106

\begin{tabular}{lc}
\multicolumn{1}{c}{ Additives } & $\begin{array}{c}\mathrm{NO}_{2}{ }^{-} / \text {cellular } \\
\text { protein }\end{array}$ \\
\hline & $n m o l / m g$ \\
None & $\mathrm{ND}$ \\
L-NMMA & $\mathrm{ND}$ \\
TNF- $\alpha+$ IFN- $\gamma$ & $1.65 \pm 0.2$ \\
TNF- $\alpha+$ IFN- $\gamma+$ L-NMMA & $\mathrm{ND}$ \\
TNF- $\alpha+$ IFN- $\gamma+$ LPS & $26.50 \pm 1.1$ \\
TNF- $\alpha+$ IFN- $\gamma+$ LPS + L-NMMA & $5.25 \pm 0.4$ \\
TNF- $\alpha+$ IFN- $\gamma+$ LPS + HC $\left(10^{-8} \mathrm{M}\right)$ & $25.00 \pm 1.2$ \\
TNF- $\alpha+$ IFN- $\gamma+$ LPS + HC $\left(10^{-7} \mathrm{M}\right)$ & $24.00 \pm 1.5$ \\
TNF- $\alpha+$ IFN- $\gamma+$ LPS + CHX & $4.00 \pm 0.5$ \\
& \\
\hline
\end{tabular}

Confluent cultures of UMR-106 cells were treated with various additives for $24 \mathrm{~h}$. Concentrations used were $100 \mathrm{ng} / \mathrm{ml} \mathrm{TNF}-\alpha ; 100$ $\mathrm{U} / \mathrm{ml} \mathrm{IFN-} \gamma ; 10 \mathrm{ng} / \mathrm{ml} \mathrm{LPS} ; 1 \mathrm{mM}$ L-NMMA; $10^{-8}$ and $10^{-7} \mathrm{M}$ hydrocortisone (HC); $10^{-6} \mathrm{M}$ cycloheximide (CHX). Data, expressed as $\mathrm{nmol} \mathrm{NO}{ }_{2}^{-} / \mathrm{mg}$ cellular protein, are means \pm SEM of three experiments, each performed in triplicate. ND, not detectable.

clastic resorption. TNF- $\alpha(10 \mathrm{ng} / \mathrm{ml})+\mathrm{IFN}-\gamma(100 \mathrm{U} / \mathrm{ml})$ $+\operatorname{LPS}(10 \mathrm{ng} / \mathrm{ml})$ induced a significant increase in the amount of $\mathrm{NO}_{2}{ }^{-}$in the culture supernatant of these bone explants after $4 \mathrm{~d}$ of culture (Fig. $6 \mathrm{~A}$ ). This increase in NO production was associated with a significant inhibition of resorption measured as ${ }^{45} \mathrm{Ca}$ release (Fig. $6 \mathrm{~B}$ ). Addition of $1 \mathrm{mM}$ L-NMMA significantly inhibited TNF- $\alpha+$ IFN- $\gamma+$ LPS-stimulated $\mathrm{NO}_{2}^{-}$production from $4.0 \pm 0.2$ to $0.9 \pm 0.2 \mathrm{nmol} \mathrm{NO}_{2}{ }^{-} /$well $(P<0.05)$, and could prevent the suppression of osteoclastic resorption (Fig. 6). Control resorption, however, was not influenced by

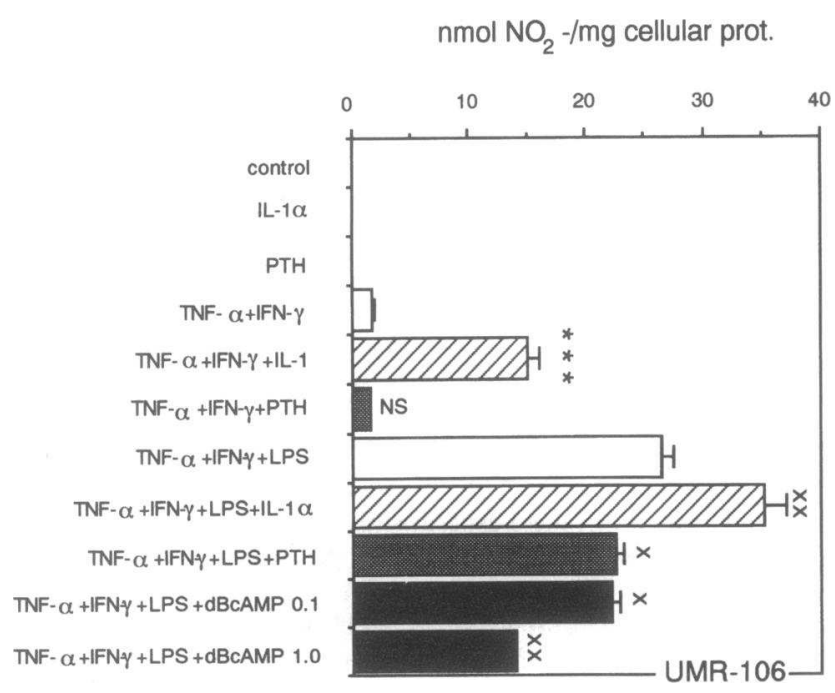

Figure 4. Effect of $40 \mathrm{nM}$ PTH (gray bars), $10 \mathrm{ng} / \mathrm{ml} \mathrm{IL-1} \alpha$ (hatched bars), and 0.1 and $1.0 \mathrm{mM} \mathrm{dBcAMP} \mathrm{(black} \mathrm{bars)} \mathrm{on} \mathrm{basal} \mathrm{or} \mathrm{stimu-}$ lated $\mathrm{NO}_{2}^{-}$production by confluent cultures of UMR-106 cells. The cells were either unstimulated or stimulated for $24 \mathrm{~h}$ with TNF- $\alpha$ $(100 \mathrm{ng} / \mathrm{ml})+$ IFN- $\gamma(100 \mathrm{U} / \mathrm{ml})$ or with TNF- $\alpha+$ IFN- $\gamma+$ LPS $(10 \mathrm{ng} / \mathrm{ml})$. Data $\left(\mathrm{nmol} \mathrm{NO}{ }_{2}^{-} / \mathrm{mg}\right.$ cellular protein $)$ are means \pm SEM of three experiments, each performed in triplicate. ${ }^{* *}$ Significantly different from TNF- $\alpha+$ IFN- $\gamma ; P<0.001$. NS, not significant. ${ }^{x}$ Significantly different from TNF- $\alpha+$ IFN- $\gamma+$ LPS; $P<0.05,{ }^{\mathrm{xx}} P<0.01$.
(A)

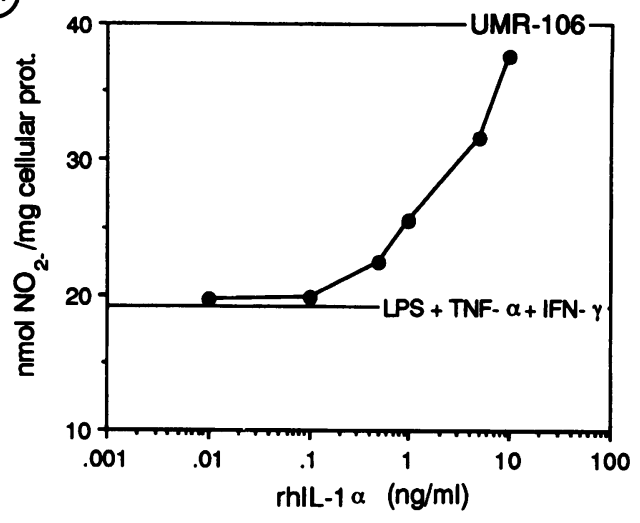

(B)

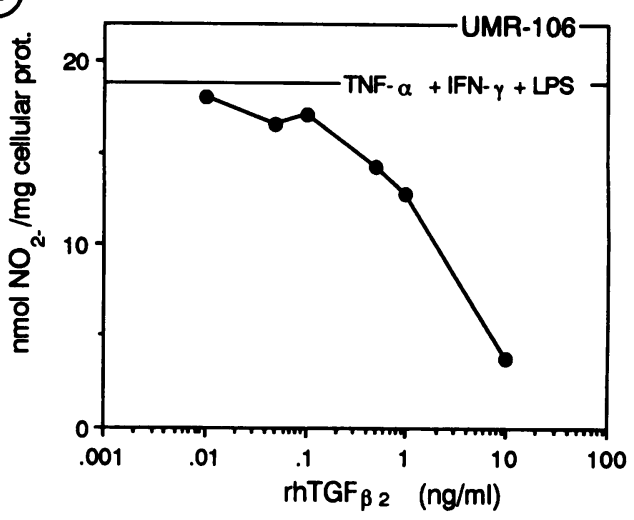

Figure 5. The effect of various doses of $(A)$ recombinant human IL$1 \alpha$ and $(B)$ recombinant human TGF- $\beta 2$ on LPS $(10 \mathrm{ng} / \mathrm{ml})$ + TNF- $\alpha(100 \mathrm{ng} / \mathrm{ml})+$ IFN- $\gamma(100 \mathrm{U} / \mathrm{ml})$-stimulated $\mathrm{NO}_{2}{ }^{-}$production by confluent cultures of UMR-106 cells after $24 \mathrm{~h}$ of incubation. Data ( $\mathrm{nmol} \mathrm{NO}{ }_{2}^{-} / \mathrm{mg}$ cellular protein) are the mean of two experiments, each performed in quadruplicate. Variation in the mean values was never $>5 \%$.

L-NMMA. These findings were confirmed by histological evaluation of the long bones (Fig. 7). In the presence of TNF- $\alpha$ + IFN- $\gamma+$ LPS (Fig. $7 C$ ), almost no osteoclasts were found but simultaneous addition of L-NMMA (Fig. $7 d$ ) totally restored osteoclastic resorption to control level (Fig. 7 b). In Fig. $8 \mathrm{~A}$, it is shown that the NO-releasing agent sodium nitroprusside stimulated the $\mathrm{NO}_{2}{ }^{-}$production in the bone cultures dose dependently, both in the absence and presence of PTH $\left(4.10^{-8}\right.$ M). Furthermore, sodium nitroprusside inhibited basal- as well as PTH-induced osteoclastic resorption measured as net ${ }^{45} \mathrm{Ca}$ release in a dose-dependent fashion.

\section{Discussion}

This study shows that various cytokines or combinations of these with LPS can induce NO production in primary rat osteoblast-like cells as well as in the clonal rat osteoblast-like cell line UMR-106. Spontaneous production of NO was, however, observed only in cultures of primary osteoblast-like cells. Whether this was due to other cells contaminating the primary osteoblast cultures (e.g., endothelial cells) or to the presence of 

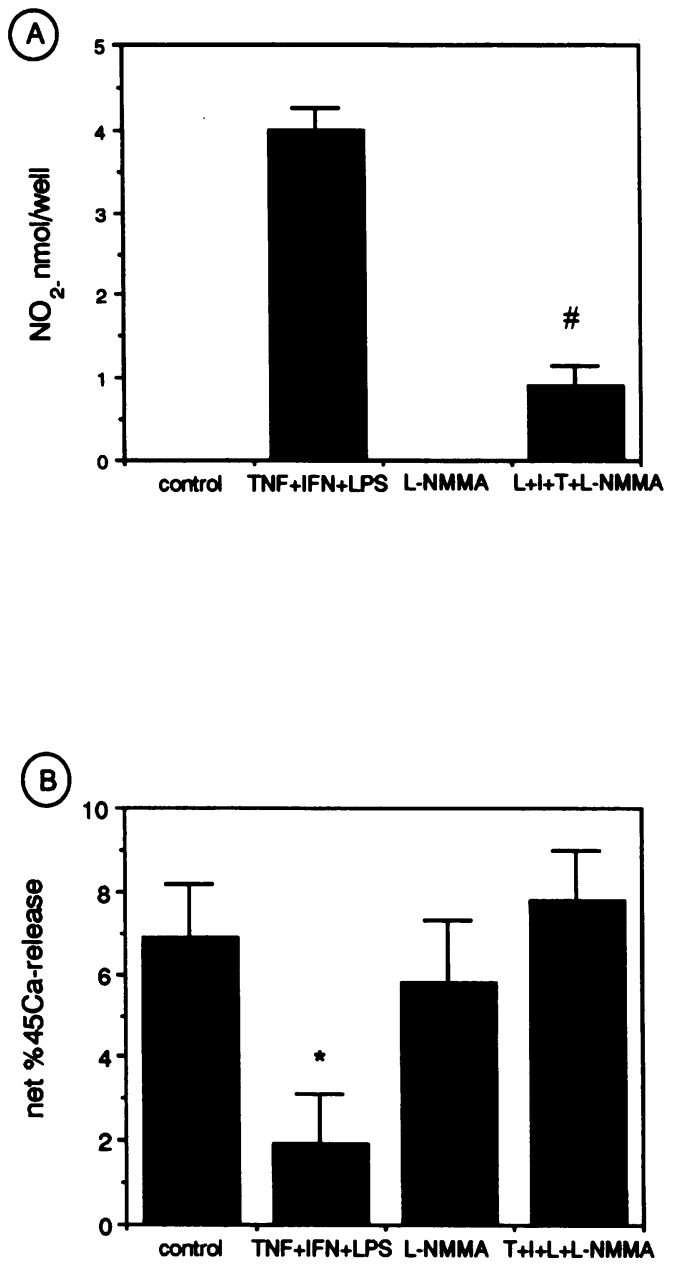

Figure 6. Effect of LPS $(10 \mathrm{ng} / \mathrm{ml})+\mathrm{IFN}-\gamma(100 \mathrm{U} / \mathrm{ml})+\mathrm{TNF}-\alpha$ $(10 \mathrm{ng} / \mathrm{ml})$ in the absence or presence of $1 \mathrm{mM} \mathrm{L}-\mathrm{NMMA}$ on $(A)$ $\mathrm{NO}_{2}{ }^{-}$production, and $(B)$ net $\%{ }^{45} \mathrm{Ca}$ release by fetal mouse long bones (shafts of 17-d-old radii) after $4 \mathrm{~d}$ of culture. Data (nmol $\mathrm{NO}_{2}{ }^{-} /$well or net $\%{ }^{45} \mathrm{Ca}$ release) are means \pm SEM of four cultures. *Significantly different from control, $P<0.05$. "Compared with LPS + IFN- $\gamma+$ TNF- $\alpha$ treated, $P<0.05$.

a constitutive NOS in normal osteoblast-like cells (as opposed to those of malignant origin) needs to be addressed in further studies. Similar to other cell types containing an inducible NOS, the increase in NO production in the UMR-106 cells started after a lag period of $6 \mathrm{~h}$ and continued thereafter. We demonstrated that the competitive inhibitor of NO production, L-NMMA, blocked stimulated NOS activity and that the induction of NO production could be inhibited by cycloheximide. Similar to chondrocytes (12-14), but in contrast to other cell types containing an inducible NOS $(22,23)$, the $\mathrm{NO}_{2}{ }^{-}$production could not be inhibited by hydrocortisone. In contrast to chondrocytes (12-14), but similar to fibroblasts (11), IL-1 $\alpha$ alone could not induce $\mathrm{NO}_{2}^{-}$production in UMR106 cells but stimulated $\mathrm{NO}_{2}{ }^{-}$production synergistically when combined with TNF- $\alpha+$ IFN- $\gamma$ or TNF- $\alpha+$ IFN- $\gamma+$ LPS. TGF- $\beta 2$ alone had also no effect on $\mathrm{NO}_{2}^{-}$production but could dose dependently inhibit TNF- $\alpha+$ IFN- $\gamma$ or TNF- $\alpha+$ IFN- $\gamma$ + LPS-induced $\mathrm{NO}_{2}{ }^{-}$production. This is in line with findings in macrophages in which TGF- $\beta 1,2$, and 3 are all able to inhibit induction of NOS activity (24).
The major bone resorbing hormone, PTH, had no effect on $\mathrm{NO}_{2}^{-}$production when added alone or in combination with TNF- $\alpha+$ IFN- $\gamma$, but had a small significant inhibitory effect on TNF- $\alpha+$ IFN- $\gamma+$ LPS-induced $\mathrm{NO}_{2}{ }^{-}$production. This was probably due to its well-known stimulatory effect on intracellular cAMP since the inhibition could be mimicked by the cAMP analogue, dibutyryl cAMP. The active metabolite of vitamin $\mathrm{D}_{3}, 1,25(\mathrm{OH})_{2} \mathrm{D}_{3}$, also a stimulator of bone resorption, had no effect on basal as well as stimulated NO production (results not shown).

Apart from mouse and rat osteoblast-like cells, NO production could also be induced in fetal mouse long bone explants by TNF- $\alpha+$ IFN- $\gamma+$ LPS and by the NO-releasing compound sodium nitroprusside. The induction of NO production by TNF $\alpha+$ IFN- $\gamma+$ LPS and by sodium nitroprusside at concentrations $>0.01 \mathrm{mM}$ was associated with a significant inhibition of basal osteoclastic resorption. The latter is in line with the findings of MacIntyre et al. (15), who reported that NO induced a rapid shape change in isolated osteoclasts that was associated with an inhibition of bone resorption when the osteoclasts were incubated for $24 \mathrm{~h}$ on devitalized bone slices. In unstimulated fetal mouse bone shafts, containing mainly osteoblasts, chondrocytes, fibroblasts, and osteoclasts, there was no detectable NO production and ${ }^{45} \mathrm{Ca}$ release could not be inhibited by L-NMMA, indicating that basal osteoclastic resorption is not regulated by a constitutive NO production. The inhibition of bone resorption by TNF $\alpha+$ IFN $\gamma+$ LPS, however, could be prevented by concurrent addition of L-NMMA, indicating that this inhibition was NO mediated, but in the presence of L-NMMA resorption was not increased above control levels. The reason for this might be that IFN- $\gamma$, apart from an effect through NO, may also act through other pathways affecting osteoclastic resorption, i.e., inhibition of osteoclast formation, as has already been suggested by Gowen et al. (25). Histological evaluation revealed that the LPS + IFN- $\gamma+$ TNF- $\alpha-$ induced inhibition of ${ }^{45} \mathrm{Ca}$ release was associated with a decrease in the number of tartrate-resistant acid phosphatasepositive osteoclasts. The absence of any evidence of cell or tissue damage makes a possible toxic effect of NO on these cells highly unlikely. The exact level of action of NO can not be deduced from these experiments. To determine if the NO-mediated decrease in osteoclasts is due to a decrease in osteoclast formation or just to a direct inhibition of osteoclast activity as described by MacIntyre et al. (15), further studies are warranted. It is remarkable that only $\mathrm{NO}_{2}{ }^{-}$levels $>2.0 \mathrm{nmol} /$ well are related to inhibition of basal bone resorption since in the presence of $0.01 \mathrm{mM}$ sodium nitroprusside or TNF- $\alpha$ + IFN- $\gamma$ + LPS + L-NMMA, the $\mathrm{NO}_{2}{ }^{-}$levels were still significantly elevated $(2.0 \pm 0.05$ and $0.9 \pm 0.2$, respectively) compared with control, but resorption was unaffected. However, PTHstimulated bone resorption was already significantly inhibited by $0.01 \mathrm{mM}$ sodium nitroprusside. Although this might just be due to the sensitivity of our resorption assay, it is possible that stimulated resorption is much more sensitive to NO-mediated inhibition than basal resorption. In this way basal resorption is not immediately influenced by small changes in NO concentrations constitutively produced by other cells, like endothelial cells, neutrophils, mast cells, platelets, and neurons, present in or near the bone compartment. However, it is likely that vasoactive, neuronal active, and other rapidly acting activators of the constitutive NOs activity can affect bone resorption through an NO-mediated pathway. 

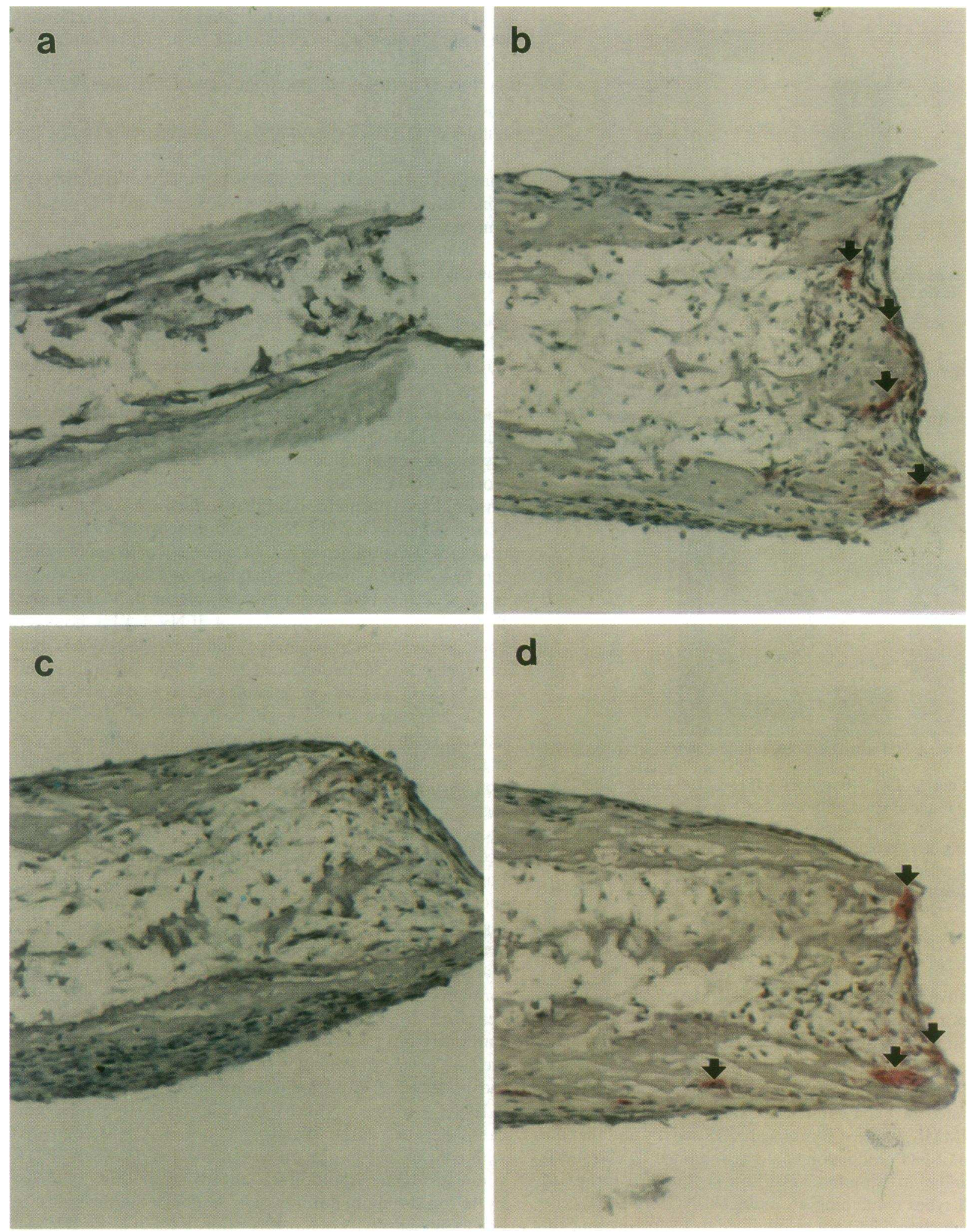

Figure 7. Transversal sections through shafts of 17-d-old radii after $4 \mathrm{~d}$ of culture. The bone explants are stained for tartrate-resistant acid phospatase (TRAcP) activity and sections are counter stained with hemotoxylin (as described in Methods). Representative sections are shown of (a) "killed" control (three cycles of freeze-thawing), (b) control, (c) LPS (10 ng/ml) + IFN- $\gamma(100 \mathrm{U} / \mathrm{ml})+$ TNF- $\alpha(10 \mathrm{ng} / \mathrm{ml})-\operatorname{treated}$ explants, and $(d)$ LPS + IFN- $\gamma$ + TNF- $\alpha$-treated explants in the presence of $1 \mathrm{mM}$ L-NMMA. In the "killed" control $(a)$ there is no sign of cellular activity. In the control cultures $(b)$ TRAcP-positive osteoclasts are found especially at the sites were trabeculae are present (arrows). In the presence of LPS + IFN- $\gamma+$ TNF- $\alpha(c)$ almost no TRAcP-positive osteoclasts are found. Simultaneous addition of 1 mM L-NMMA (d) totally restores LPS + IFN- $\gamma+$ TNF- $\alpha$-inhibited osteoclastic resorption back to control levels. Note the reoccurence of TRAcP osteoclasts (arrows). 

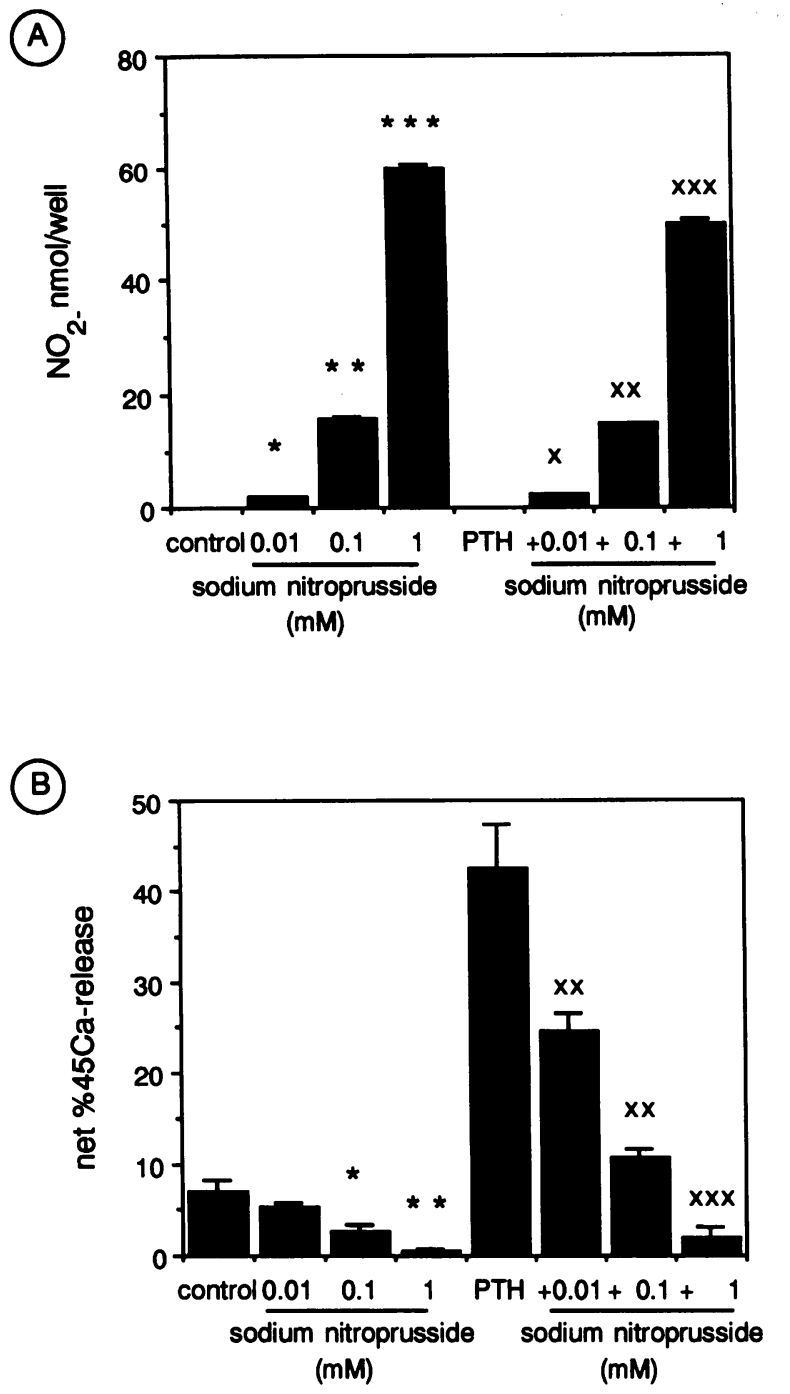

Figure 8 . The effect of the NO donor sodium nitroprusside in the absence or presence of $40 \mathrm{nM}$ PTH on $(A) \mathrm{NO}_{2}^{-}$production, and $(B)$ net $\%{ }^{45} \mathrm{Ca}$ release by fetal mouse long bones (shafts of 17 -d-old radii) after $4 \mathrm{~d}$ of culture. Data $\left(\mathrm{nmol} \mathrm{NO} \mathrm{NO}_{2}^{-} /\right.$well or net $\%{ }^{45} \mathrm{Ca}$ release $)$ are means \pm SEM of four cultures. *Significantly different from control; $P$ $<0.05,{ }^{* *} P<0.01,{ }^{* * *} P<0.001$. ${ }^{*}$ Compared with PTH treated; $P<0.05,{ }^{\mathrm{xx}} P<0.01,{ }^{\mathrm{xxx}} P<0.001$.

An important question that arises whenever animal tissues or cells are used is whether the findings can be directly applicable to human physiology. Although induction of NO synthesis by cytokines has not been found in human macrophages, it was recently shown that human articular chondrocytes express an inducible NOS (14). Compared with the NOS present in rabbit chondrocytes (13), the human enzyme differs in its sensitivity to calcium and glucocorticoids. However, it was shown that the NOS in both species belonged to the same family as the NOS expressed in rodent macrophages (14). As chondrocytes are osteogenic cells, these findings in rodent bone cells are likely to be relevant to human cells as well.

At this stage we can only speculate about the clinical relevance of our observations. Our hypothesis is that NO production may represent a protective mechanism against unopposed bone resorption during pathological conditions, such as for example during inflammation. As the inflammatory cytokines IL-1 and TNF as well as LPS are known stimulators of osteo- clastic bone resorption (26), one would expect considerable bone loss during the course of inflammatory processes, which is not the case. IFN- $\gamma$, which is also produced during inflammation by activated $\mathrm{T}$ lymphocytes, appears to be the key regulator of this protective mechanism. In the presence of TNF- $\alpha$, IL-1, and LPS, IFN- $\gamma$ induces NO production, which enhances the immune function but in addition prevents bone resorption induced by IL-1 and TNF. If this hypothesis is correct then in conditions with impaired IFN- $\gamma$ production one would expect to find increased bone loss. This is in fact the case in rheumatoid arthritis in which activated $\mathrm{T}$ lymphocytes have been shown to have an impaired production of IFN- $\gamma$ compared with controls (27). The systemic stimulators of bone resurption, PTH and $1,25(\mathrm{OH})_{2} \mathrm{D}_{3}$, involved in the normal control of bone metabolism have no effect on NO production on their own or in the presence of IFN- $\gamma$. This strengthens further the hypothesis that the stimulation of the NO pathway appears to be an important regulator of osteoclast activity only under pathological conditions characterized by release of bone resorbing inflammatory cytokines. Our hypothesis is supported by the findings of Gowen et al. (25), showing that IFN- $\gamma$ strongly inhibited bone resorption induced by TNF or IL-1 but not that induced by PTH and $1,25(\mathrm{OH})_{2} \mathrm{D}_{3}$.

In conclusion, NO produced by osteogenic cells (osteoblasts and chondrocytes) may be an important regulator of osteoclast activity especially in conditions characterized by elevated local release of inflammatory, bone resorbing cytokines. These findings might open new perspectives in the approach of bone disorders characterized by increased osteoclastic bone resorption like high turnover osteoporosis, hypercalcemia due to metastatic bone disease, Paget's disease, and rheumatoid arthritis.

\section{Acknowledgments}

This work was partially supported by the Netherlands Organisation for the Advancement of Pure Research (NWO, 900-541-191).

\section{References}

1. Moncada, S., R. M. J. Palmer, and E. A. Higgs. 1991. Nitric oxide: physiology, pathophysiology and pharmacology. Pharmacol. Rev. 43:109-142.

2. Nathan, C. 1992. Nitric oxide as a secretory product of mammalian cells. FASEB (Fed. Am. Soc. Exp. Biol.) J. 6:3051-3064.

3. Lowenstein, C. J., and S. H. Snyder. 1992. Nitric oxide, a novel biological messenger. Cell. 70:705-707.

4. Stuehr, D. J., and C. Nathan. 1989. Nitric oxide: a macrophage product responsible for cytostasis and respiratory inhibition in tumor target cells. J. Exp. Med. 169:1543-1545.

5. Nathan, C., and J. B. Hibbs, Jr. 1991. Role of nitric oxide synthesis in macrophage antimicrobial activity. Curr. Opin. Immunol. 3:65-70.

6. Hibbs, J. B., Jr., R. R. Taintor, Z. Vavrin, D. L. Granger, J.-C. Drapier, I. J. Amber, and J. R. Lancaster, Jr. 1990. Synthesis of nitric oxide from guanidino nitrogen of L-arginine: a molecular mechanism that targets intracellular iron. In Nitric Oxide from L-arginine: A Bioregulatory System. S. Moncada and E. A. Higgs, editors. Elsevier Science Publishers B.V., Amsterdam. 189-223.

7. Bredt, D. S., P. M. Hwang, C. E. Glatt, C. Lowenstein, R. R. Reed, and S. H. Snyder. 1991. Cloned and expressed nitric oxide synthase structurally resembles cytochrome P-450 reductase. Nature (Lond.). 351:714-718.

8. Lamas, S., P. A. Marsden, G. K. Li, P. Tempst, and T. Michel. 1992. Endothelial nitric oxide synthase: molecular cloning and characterization of a distinct constitutive enzyme isoform. Proc. Natl. Acad. Sci. USA. 89:6348-6352.

9. Xie, Q.-W., H. J. Cho, J. Calaycay, R. A. Mumford, K. M. Swiderek, T. D. Lee, A. Ding, T. Troso, and C. Nathan. 1992. Cloning and characterization of inducible nitric oxide synthase from mouse macrophages. Science (Wash. DC). 256:225-228.

10. Nussler, A. K., M. di Silvio, T. R. Billiar, R. A. Hoffmann, D. A. Geller, R. 
Selby. J. Madariaga, and R. L. Simmons. 1992. Stimulation of the nitric oxide synthase pathway in human hepathocytes by cytokines and endotoxin. J. Exp. Med. 176:261-266.

11. Werner-Felmayer, G., E. R. Werner, D. Fuchs, A. Hausen, G. Reibnegge, and $H$. Wachter. 1990. Tetrahydrobiopterin-dependent formation of nitrite and nitrate in murine fibroblasts. J. Exp. Med. 172:1599-1607.

12. Stadler, J., M. Stefanovic-Racic, T. R. Billiar, R. D. Curran, L. A. McIntyre, H. I. Georgescu, R. L. Simmons, and C. H. Evans. 1991. Articular chondrocytes synthesize nitric oxide in response to cytokines and lipopolysaccharide. $J$. Immunol. 147:3915-3920.

13. Palmer, R. M. J., T. Andrews, N. A. Foxwell, and S. Moncada. 1992. Induction of nitric oxide synthase in human chondrocytes. Biochem. Biophys. Res. Commun. 188:209-215.

14. Palmer, R. M. J., M. S. Hickery, I. G. Charles, S. Moncada, and M. T. Bayliss. 1993 Biochem. Biophys. Res. Commun. 193:398-405.

15. MacIntyre, I., M. Zaidi, A. S. M. Towhidul Alam, H. K. Datta, B. S. Moonga, P. S. Lidbury, M. Hecker, and J. R. Vane. 1991. Osteoclastic inhibition: an action of nitric oxide not mediated by cGMP. Proc. Natl. Acad. Sci. USA. 88:2936-2940.

16. Rodan, G. A., and T. J. Martin. 1981. Role of osteoblasts in hormonal control of bone resorption: a new hypothesis. Calcif. Tissue Int. 33:349-351.

17. Vaes, G. 198. Cellular biology and biochemical mechanism of bone resorption. Clin. Orthop. Relat. Res. 231:239-271.

18. Boonekamp, P. M., J. W. Hekkelman, D. V. Cohn, and R. L. Jilka. 1984. Effect of culture on hormone responsiveness of bone cells isolated by an improved sequential digestion procedure. Proc. K. Ned. Acad. Wet. Ser. B. Phys. Sci. $87: 371-381$.
19. Partridge, N. C., D. Alcorn, V. P. Michelangeli, G. B. Ryan, and T. J. Martin. 1983. Morphological and biochemical characterization of four clonal osteogenic sarcoma cells of rat origin. Cancer Res. 43:4308-4314.

20. Stern, P. A., and L. G. Raisz. 1979. Organ culture of bone. In Skeletal Research and Experimental Approaches. D. J. Simmons and A. S. Kunin, editors. Academic Press, New York. 21-59.

21. Scheven, B. A. A., E. W. M. Kawilarang-de Haas, A. M. Wassenaar, and P. J. Nijweide. 1986. Differentiation kinetics of osteoclasts in the periosteum of embryonic long bones in vivo and in vitro. Anat. Rec. 214:418-423.

22. Moncada, S., and R. M. J. Palmer. 1991. Inhibition of the induction of nitric oxide synthase by glucocorticoids: yet another explanation for their anti-inflammatory effects. Trends Pharmacol. Sci. 12:130-131.

23. Di Rosa, M., M. Radomski, R. Carnuccio, and S. Moncada. 1990. Glucocorticoids inhibit the induction of nitric oxide synthase in macrophages. Biochem. Biophys. Res. Commun. 172:1246-1252.

24. Ding, A., C. F. Nathan, J. Graycar, R. Derynck, D. J. Stuehr, and S. Srimal. 1990. Macrophage deactivation factor and transforming growth factors$\beta-1,-2$, and -3 inhibit induction of macrophage nitrogen oxide synthesis by interferon- $\gamma$. J. Immunol. 145:940-944.

25. Gowen, M., G. E. Nedwin, and G. R. Mundy. 1986. Preferential inhibition of cytokine-stimulated bone resorption of recombinant interferon gamma. J. Bone Miner. Res. 1:469-473.

26. Gowen, M. 1992. Interleukin 1 and tumor necrosis factor. In Cytokines and Bone. M. Gowen, editor. CRC Press, Inc., Boca Raton. 72-91.

27. Stolzenburg, T., R. Binz, A. Fontana, M. Felder, and F-J. Wagenhaeuser. 1988. Impaired mitogen-induced interferon gamma production in rheumatoid arthritis and related diseases. Scand. J. Immunol. 27:73-82. 